Assessing the decennial, reassessing the global

Understanding European Union normative power in global politics

Manners, lan James

Published in:

Cooperation and Conflict

DOI:

$10.1177 / 0010836713485389$

Publication date:

2013

Document version

Publisher's PDF, also known as Version of record

Citation for published version (APA):

Manners, I. J. (2013). Assessing the decennial, reassessing the global: Understanding European Union normative power in global politics . Cooperation and Conflict, 4(3), 304-329.

https://doi.org/10.1177/0010836713485389 


\title{
Assessing the decennial, reassessing the global: Understanding European Union normative power in global politics
}

Cooperation and Conflict 48(2) 304-329

(C) The Author(s) 2013

Reprints and permissions: sagepub.co.uk/journalsPermissions.nav DOI: $10.1177 / 00108367 \mid 3485389$ cac.sagepub.com @SAGE

\section{Ian Manners}

\begin{abstract}
This concluding article assesses the past decade of international scholarship on the European Union (EU) and normative power as represented by the contributions to the special issue. It argues that the normative power approach (NPA) makes it possible to explain, understand and judge the EU in global politics by rethinking the nature of power and actorness in a globalizing, multilateralizing and multipolarizing era. To do this, the article assesses the past decade in terms of normative power engagement, internationalization and comparison. The article then argues that rethinking power and actorness involves reassessing global theory and pouvoir normatif in action. The article concludes by setting out three ways of developing the NPA in its second decade: macro-approach, meso-characterization and micro-analysis. Following the suggestion of Emanuel Adler, Barry Buzan and Tim Dunne, the article sets out how studying the normative foundations of power through the NPA combines the normative rethinking of power and actorness with the structural changes of a globalizing, multilateralizing and multipolarizing era.
\end{abstract}

\section{Keywords}

European Union, globalizing, multilateralizing, multipolarizing, normative power

\section{Introduction}

This concluding article assesses the past decade of international scholarship on the European Union (EU) and normative power as represented by the contributions to the special issue. It will argue that the normative power approach (NPA) makes it possible to explain, understand and judge the EU in global politics by rethinking the nature of power and actorness in a globalizing, multilateralizing and multipolarizing era.

\section{Corresponding author:}

Ian Manners, Department of Political Science, University of Copenhagen, Øster Farimagsgade 5, DK-I 353

Copenhagen K, Denmark.

Email:ima@ifs.ku.dk 
The previous articles all attest to the international interest in the idea of normative power, either in the case of the EU or increasingly in non-EU cases. Over the past decade this interest can be found in at least a dozen scholarly works (Adler et al., 2006; Aggestam, 2008; Gerrits, 2009; Kavalski, 2012; Laïdi, 2008a, 2008b; Lucarelli and Manners, 2006; Manners, 2010c; Sicurelli, 2010; Sjursen, 2006; Tocci, 2008; Whitman, 2011). Thus the first part of the article assesses the decennial by interrogating the special issue contributions and wider debates for what they have to say about international and comparative engagement with the notion of normative power over the past 10 years. The emphasis in this first part will be on the international dimension of normative power approaches and how we might study other international actors in a comparative way. In this part the article looks at, first, the extent to which the contributions reflect a mainstream scholarly engagement with EU studies providing a contribution to the international relations discipline and scholarship on 'global studies' more generally. Second, the contributions will be examined for evidence of the internationalization of the NPA across and outside Europe. What becomes clear in these first two discussions is that there are at least three meanings of normative power present in international scholarship. The third step is to use the contributions to develop an understanding of how the NPA can be used to compare the EU with other global actors. Here the concept of pouvoir normatif is developed to facilitate such a comparison. Finally, the first part summarizes how international and comparative engagement, including the contributions, have contributed to the conceptualization of normative power.

The contributions to this special issue also say something interesting about reassessing 'the global' and how this reassessment is part of reflecting on the NPA. Thus the second part of the article reassesses the global through the contributions to the special issue. The second part focuses on the extent to which global changes over the past decade cause us to rethink the nature of power and actorness in the 21 st century. In this part, the article first reassesses the global by suggesting that our globalizing, multilateralizing and multipolarizing era requires a reconsideration of the nature of power and actorness. Here it is useful to reflect on the four ways in which pouvoir normatif may be theorized. This reconsideration is necessary because processes of globalization have empowered transnational actors such as global credit rating agencies; because multilateralizing processes have empowered international fora such as the G20; and because multipolarizing processes have empowered emerging actors such as the BRICS (Brazil, Russia, India, China and South Africa). Second, the global is reassessed by rethinking the nature of power, in particular because breaking old dichotomies of 'hard power' vs 'soft power' demands the reintroduction of an ideational dimension in the form of normative power. Here a discussion of pouvoir normatif in action is useful in illustrating a rethinking of the nature of power. Third, within this context of power and actors the article rethinks actorness because new global actors, such as transnational movements, regional organizations, global governors and emerging economies, demand new thinking on how they are constituted through their use of new forms of power. Finally, the article concludes by arguing the global - that, in this global era, the rethinking of power and actorness are crucial aspects of understanding the EU and understanding normative power in global politics. It goes further by setting out three ways of developing the NPA in its second decade: macro-approach, meso-characterization and micro-analysis. 


\section{Assessing the decennial}

For some the concept of normative power has 'significantly influenced debates' (Diez, 2013), while for others it contains a normative imperative which could 'reinvigorate European agency' (Fisher Onar and Nicolaïdis, 2013). Other contributors argue for a more global approach to include the tensions in the EU's 'plural ontological realities' (Parker and Rosamond, 2013), involved in a powerful struggle over the 'naming of powers' (Keene, 2013), with the 'rise of normative powers' in global life (Kavalski, 2013). Whether scholars like it or not, critique it or use it for critique, assessing the decennial of the NPA is very different from the scholarly debates of the 1990s. The rest of this assessment of the decennial focuses on the engagement, internationalization, comparison and conceptualization of normative power approaches, using the contributions to this volume as a prism for understanding wider discussions.

\section{Assessing engagement, internationalization and comparison}

The articles contributing to this special issue illustrate the extent to which there is an increasing mainstream scholarly engagement between the discipline of international relations and the study of normative power. All of the contributions are primarily concerned with the engagement between EU studies and international relations concepts, theories and fields outside Europe. Similarly, none of the contributors fits neatly into a single, simple description such as international relations theorist, EU specialist, comparative regionalist, political theorist or international political economist. Thus, assessing wider engagement between disciplines such as politics, economics, sociology or law and normative power reveals a broad and complex horizon of single-, multi- and interdisciplinary scholarship. As Diez (2013) discusses in his contribution, the NPA may be 'successful across the disciplines' because it is 'easier to swallow for the mainstream'. In terms of assessing engagement, the contributors and the works cited serve as illustrations of the extent to which international relations and normative power scholarly engagement have grown over the decade. As Emanuel Adler, Barry Buzan and Tim Dunne have suggested:

If the normative and the structural are to be combined, the synthesis should follow E. H. Carr in taking knowledge and power and values and interests as two sides of the same (social reality) coin. Inching toward a synthesis, thus, would consist of, for example, studying the normative foundations of power - Ian Manners' concept of Normative Power shows the way.

(Adler et al., 2005: 197-198)

The majority of normative power work is found spread across Europe, as illustrated by the contributions from the UK (Kent, Oxford and Warwick), Germany (Tübingen), Denmark (Copenhagen) and Turkey (Bahcesehir, Istanbul) in this special issue. This assessment of internationalization is reinforced by normative power scholarship by Christopher Bickerton (2011a, 2011b) and Zaki Laïdi (2008a, 2008b) 
at Science Po, Paris; Annika Björkdahl (2008, 2011) in Lund; Tuomas Forsberg (Forsberg, 2011; Forsberg and Seppo, 2009) in Helsinki; Hiski Haukkala (2008, $2011)$ in Tampere; Robert Kissack $(2009,2010)$ in Barcelona; Mary Martin and Mary Kaldor (Kaldor, 2012; Kaldor et al., 2007; Martin, 2011) at the London School of Economics and Political Science, London; Jan Orbie (2006, 2011) in Ghent; Michelle Pace (2007; Diez and Pace, 2011) in Birmingham; and Daniela Sicurelli in Trento and Sibylle Scheipers in St Andrews (Scheipers and Sicurelli, 2007, 2008; Sicurelli, 2010).

However, there is also evidence of a wider pattern of internationalization beyond Europe, including in the USA, Canada, Israel, Australia, Japan and China. This wider pattern provides examples of how ideas of normative power have internationalized in terms of both location and application. Engagement with the NPA in the USA includes the work of Jennifer Mitzen (2006, 2011), Vicki Birchfield (2011, in press) and Sarah Cormack Patton $(2009,2012)$. The work of Emanuel Adler both in Jerusalem and in Toronto has been important (Adler et al., 2006; Adler and Crawford, 2006). Subsequent Israel-based scholarship has followed this lead (e.g. Harpaz, 2007; Harpaz and Shamis, 2010; Huber, 2012). In Australia engagement includes the work of Tim Dunne $(2008,2012)$ in Brisbane, Steve Wood $(2009,2011)$ in Sydney and Philomena Murray (2010, in press) in Melbourne. Japanese approaches include the work of Yoichiro Usui (2003, 2011), Eijiro Fukui (2009, 2012) and Yuichi Hosoya (2012), as well as aspects of Isao Sakaguchi's and Daisaku Higashi's contributions to Tiberghien (2013) discussed below. Finally, outside Europe the greatest interest in normative power is to be found amongst Chinese scholarship. According to Stumbaum (2012: 14-15), early Chinese normative power scholarship was limited and included the work of Hongwei Cui (2007), Lilei Song (2008), Ming Zhang (2008) and Yiwei Wang (2009). Later scholarship began taking first steps towards engagement, as found in the work of Lei Ji (2010), Yousheng Hong (2010), Lilei Song and Zhimin Chen (2011), Wenwen Shen (2011a, 2011b, 2012), Zhongqi Pan (2012) and Shumei Chen et al. (2012).

While all of the contributions to the special issue seek to advance the study of normative power beyond the EU in some way, the contributions by Keene (2013) and Kavalski (2013) engage in specific comparisons. Keene's approach is historically comparative in looking at the historical discourse of powers and 'great powers' over time. Kavalski's contribution compares the EU and China in the struggle for recognition of normative powers. Interestingly, Parker and Rosamond (2013) also engage in a different form of comparison between the two ideal types of a cosmopolitan post-Westphalian vs. a sovereign statist Westphalian political entity. These contributions illustrate one aspect of the NPA: that it facilitates comparison of state and non-state entities over time and space (see Tocci and Manners, 2008). There are a number of examples of scholarship that seeks to compare normative power in this way, including edited volumes by Tocci (2008), Gerrits (2009) and Tiberghien (2013), as well as the more extensive comparisons of Kavalski (2012) which examine the EU, China and India in central Asia. More specific comparisons look at Brazil (Lazarou, 2011), China (Callahan and Barabantseva, 2012; Womack, 2008), India (Bava, 2006; Kumar, 2008), Russia (Makarychev, 2008; Romanova, 2009; Steinkohl, 2010) and the USA (Diez, 2005; Hamilton, 2008). 


\section{Assessing conceptualization}

French has two words to translate 'Macht' and 'power': 'pouvoir' and 'puissance' ... One has the puissance to do something, and one exercises the pouvoir to do it ... This distinction would be roughly that between potential and act. It is not unhelpful to recall that in English 'power' depending on the particular case, is applied to either a 'potential' or an 'act'.

(Aron, 1986: 255-256)

The social sciences have many different understandings of 'normative power', but in EU studies normative power has three particular meanings. Tuomas Forsberg (2011: 8-9) has drawn on Raymond Aron to help differentiate between two of these meanings: Aron distinguished between puissance - the potential to do something - and pouvoir - the act of doing something. This distinction is similar to that made between 'une grande puissance régionale', a type of regional great power, and 'une nouvelle forme de pouvoir normatif', a new form of normative power (Manners, 2006c: 48). Thus a distinction is made between a normative form of power, or pouvoir, and a normative ideal type of actor, or puissance. While this conceptualization of a normative form of power is made in reference to the EU, it may be of wider use in the study of global politics. The rest of this section assesses what the contributions to the special issue add to the conceptualization of normative power.

The first meaning of normative power is its emphasis on normative theory, that is how we judge and justify truth claims in social science. The contributions demonstrate a rich array of theoretical perspectives including historical materialism, critical political economy, international political thought, communities of practice and postcolonial approaches. Drawing on Antonio Gramsci's work, Diez's (2013) article advocates a focus on 'hegemonic struggles' as a critical theory that problematizes the present in order to place the politics of normative power centre stage. Drawing on Michel Foucault's work on economic liberalism, Parker and Rosamond (2013) set out how adopting a normative power approach might work together with the normative power position as a contingent intervention in a political debate. Their label of the NPA as a 'normative power Europe critical ontology' (NPE-CO), or as an approach to the study of Europe, fits this first emphasis on normative theory well. Located in the history of international political thought, and in particular in the 'English school' work of Martin Wight and Hedley Bull, Keene's (2013) article argues that there is something genuinely novel about ideas such as normative power as they represent a different way of appropriating the discourse of powers. Situated in Emanuel Adler's use of a practice approach, Kavalski's (2013) article argues that interactions, deliberative relations and communities of practice provide a means of examining how the rise of normative powers leads to a 'balance of practices'. Finally, using the work of postcolonial scholars such as Dipesh Chakrabarty, Fisher Onar and Nicolaïdis's (2013) article argues for a decentring agenda that facilitates the exploration of the ways in which normative powerhood can be shared with other actors in the international system. All of the articles make a contribution to the normative theory of normative power and argue the necessity of hegemonic struggles, the critique of market 
cosmopolitanism, the discourse of power, the balance of practices, and decentring in understanding and advocating an NPA.

The second meaning of normative power is as a form of power (pouvoir) that is ideational rather than material or physical. Diez's (2013) article is focused on hegemony as a form of power that combines material (economic) and discursive elements, although their exact mix is disputed. Parker and Rosamond (2013) emphasize the EU's economic liberal tools in the form of the externalization of internal market policies as a significant form of power. Keene's (2013) article focuses on the practice of naming of power, suggesting that the power of naming is so important that it is often the focus of fierce political struggle. Kavalski's (2013) article focuses on practices of interaction, deliberative relations and communities of practice in a comparison of EU and Chinese normative forms of power. Fisher Onar and Nicolaïdis's (2013) article focuses on renewing EU praxis in a non-European world by emphasizing engagement and reconstruction of praxis of Europe's international relations in a more inclusive fashion. Diez (2013), Parker and Rosamond (2013), Keene (2013), Kavalski (2013), and Fisher Onar and Nicolaïdis (2013) set out how the NPA can engage with international relations approaches to hegemony, critical political economy, international political thought, international practice and postcolonialism. All of the contributions argue the need to focus on the practice and praxis of normative forms of power, whether discursively, inclusively or comparatively.

The third meaning of normative power is as a characterization of an ideal type of global actor (puissance). Diez (2013) contrasts a normative power ideal type against those of 'great power' and 'civilian power' in order to examine the differences on issues of use of military power and binding to international norms. Parker and Rosamond (2013) emphasize the constitutive importance of economic liberalism in their characterization of the EU's 'market cosmopolitanism'. Their label of the NPA as a 'normative power Europe ontological reality' (NPE-OR), or as an ontological characterization of the EU as a power in international affairs, fits this third meaning of normative power well. Keene (2013) interrogates the discourse of powers as a way of framing international actorness which is neither pre- nor post-Westphalian. Kavalski (2013) goes further to compare ideal types of 'normative power Europe' and 'normative power China' with each other rather than with other ideal types of global actors. Fisher Onar and Nicolaïdis (2013) explore the ways in which normative powerhood can be reconstructed as a global public good which can be shared with other actors in the international system. What emerges from the contributions is a means of analysing ideal types of normative puissance actors by comparing them with existing ideal types (e.g. great powers or civilian powers), with other normative powers, or with the historical discourse of powers.

Having briefly assessed engagement, internationalization, comparison and conceptualization of normative power, this decennial reflection will assess and develop the concept of pouvoir normatif in order to facilitate international comparison.

\section{Assessing 'pouvoir normatif'}

Le pouvoir normatif de l'UE s'appuie sur la persuasion et l'argument, et non pas sur l'action ou la création de structures de changement. La puissance est dans ce cas une forme discursive qui 
renvoie à la légitimité et le caractère cohérent d'un argument. Dans son analyse, Manners met l'accent sur l'impact idéel de l'identité et du rôle international de l'Union européenne. Il introduit la notion de puissance normative (normative power), qui serait enracinée dans un contexte historique, un système politique hybride et une construction politico-légale ayant contribué à l'engagement de mettre les normes et les principes universels au centre des relations extérieures de l'UE.

(Saurugger, 2010: 368-369)²

As introduced in the previous section, normative pouvoir takes a form of power that is ideational rather than material or physical. As the extract from Sabine Saurugger's book on Theories and Concepts of European Integration illustrates, it makes sense to differentiate between 'le pouvoir normatif de l'UE' and 'la notion de puissance normative'. Thus, with a normative form of power, the emphasis is on the ability to use normative justification rather than on an ability to use material incentives or physical force (see discussion of the normative form of power in Manners, 2009a, 2009b, 2010c, 2011a).

In order to more fully understand the concept of pouvoir normatif it is necessary to differentiate the ability to use normative justification from that of the use of material incentives or physical force. This differentiation involves examining the historical evolution of the 'trinity of power' as it has emerged over the past 100 years. The most common and long-lasting conception of power in the social sciences is the 'trinity of power': a distinction between three forms of power resources. Writing in 1914, Max Weber suggested that a trinity of parties, classes and status groups (stände) were three dimensions of the multiplicity of power forms found in society (Weber, 1968). In his 1919 lecture on 'politics as a vocation', Weber argued that dominant powers used three means to maintain their dominance: physical violence, material reward and social honour (Weber, 1991: 80-81). Almost a century later, Gianfranco Poggi asserts that Weber's trinity of power still has relevance, with 'party' reflecting 'political power', 'class' reflecting 'economic power' and 'status' reflecting 'ideological/normative power' (Poggi, 2001: 1528). Poggi argues that similar trinities of power can be found in the works of at least six major social scientists besides Weber (Poggi, 2006: 135-149).

Three other interesting examples of such trinities include those in the works of Amatai Etzioni, John K. Galbraith and Kenneth Boulding. Etzioni's work in 1961 suggested a three-fold typology of compliance structures and strategies in complex organizations: coercion, utilitarian power and normative power (Etzioni, 1961). Galbraith's 1983 study of the trinity of power differentiated between 'condign power' (the imposition of preferences), 'compensatory power' (the offering of reward) and 'conditioned power' (the changing of belief) (Galbraith, 1983: 4-6). Similarly, Boulding's 1989 Three Faces of Power contrasted 'destructive power' (the power of threat), 'productive power' (the power of exchange) and 'integrative power' (the power of love) (Boulding, 1989: 2329). Interestingly, a similar classification for the study of the European community was suggested, although not used, by Johan Galtung in 1989 when he stated that there were 'three classical types of power: the stick, the carrot, and the idea: coercive, remunerative, and normative power' (Galtung, 1989: 15). The concept of pouvoir normatif draws on these trinities of power to examine the EU, or any other actor, in global politics. Such an 
approach is particularly attractive in helping to overcome the many problems presented by popular dichotomies such as civilian/military power, soft/hard power, Kant/Hobbes or Venus/Mars.

To conclude these decennial assessments, it is worth reflecting that the concept of normative power is important across the social sciences, although with slightly different meanings in differing disciplines, as four examples illustrate. In political philosophy 'normative power is understood as the power to affect the extant norms and beliefs that directly or indirectly affect how individuals perceive and are able to attend to their ... needs' (Hamilton, 2003: 71); in legal studies 'normative power is the ability to take decisions that change what a person ought or ought not to do, or may or may not do, or what a person is able or unable to do, in the framework of some normative order, with or without the other person's consent to this change' (McCormick, 1998: 496); and in negotiation studies 'normative power has no strategic function. In essence, normative power stems from beliefs about what constitutes a just or fair distribution' (Polzer et al., 1995: 124-125). In this special issue, Kavalski (2013) also identifies the sociological work of Jay Jackson (1975: 237-239) in defining normative power as 'the potential for influencing activity ... [through] the power of norms'.

\section{Reassessing the global}

The global environment in which the EU and other actors are constituted has changed significantly over the past 10 years, as the international system of the 16th century (Keene, 2013) gives way to the global life of multipolarity (Kavalski, 2013). The contributions provide illustrations of what a reassessment of the global might look like in terms of regionalizing, globalizing, multilateralizing and multipolarizing processes, as well as status in international society (Keene, in press). Parker and Rosamond (2013) argue that economic liberalism has been a key driver of processes such as Europeanization and globalization, through which governance transcends traditional nation state jurisdictional boundaries. Kavalski (2013) places emphasis on 'what a multi-polar theory of international relations might look like' through 'the parallel investigation of normative power' and the 'contextual exploration of the intellectual foundations not only of multi-polarity, but also to the proliferation of a cacophony of normative languages in global life'. Fisher Onar and Nicolaïdis (2013) talk about the effects of 'today's post-Cold War, post-9/11, globalizing world' and the 'turbulent waters of our emergent multipolar order' where 'the EU's resources and experience, divested of imperialism, can contribute constructively to our emergent global order'. The contributions discuss in some way the reassessment of the global and what this means for international society, whether in relation to hegemony (Diez, 2013), the political struggle of the power of naming (Keene, 2013), 'the communicative process in the international society of states' (Kavalski, 2013) or pluralism and solidarism (Fisher Onar and Nicolaïdis, 2013). What this assessment suggests is that such widespread global transformations necessitate a rethinking of both power and actorness, in particular through reassessing global theory (see Manners, 2010b, in press-a). 


\section{Reassessing global theory}

All theory in International Relations is normative theory. By this I mean that even those engaged in positivist approaches, who aim to study world politics in a manner that resembles as closely as possible the methods of natural science, cannot avoid normative assumptions in the selection of what data is important, in interpreting that data, and in articulating why such research is significant

(Cochran, 1999: 1, in Manners, 2011a: 227)

Following the brief discussion of normative theory and reassessing the global, the need to reassess global theory and theorize pouvoir normatif in order to understand more normative forms of power becomes clearer. In the context of global theory and Molly Cochran's observation on international relations, if all international relations theory is normative theory, then what are the consequences of normative assumptions regarding theory selection? As set out over a decade ago, there are at least four perspectives to theorizing and understanding pouvoir normatif in global politics: positivism and the role of 'utilitarian norms'; interpretivism and the role of 'social norms'; critical theory and the role of 'maxim norms'; and postmodern science and the role of 'narrative norms' (Manners, 2000a: 31-32, 2011a: 228; see also Manners, 2011b: 3-8). A fuller discussion of these four perspectives helps to illustrate how they might aid in the understanding 'pouvoir normative' in the context of global theory.

The study of international norms in academic circles exploded during the 1990s, a reflection of both the impact of the end of the Cold War and the popularity of social constructivism in international relations (Manners, 2000a: 31-32). By 2000 there were several surveys of this US-International Relations body of literature that gave a sense of the way in which the debate had developed, for example Ann Florini's 'The evolution of international norms' (1996), Martha Finnemore and Kathryn Sikkink's 'International norm dynamics and political change' (1998), Vaughn Shannon's 'Norms are what states make of them' (2000) and Hendrik Spruyt's 'The normative basis of the modern state order' (2000). What was strange about many of these articles was the tendency to overlook the centrality of international norms in the study of international relations prior to the mid-1980s, and in particular the concern that the English School placed on solidarist international norms in international law, humanitarian intervention and human rights. Using a series of theoretical surveys from the period 1996-2007, four theoretical perspectives on norms can identified: utilitarian, social, maxim and narrative norms (Manners, 1996: 35-50, 2000a: 31-32, 2000b: 22-35, 2007a).

Situated within notions of positivism are utilitarian norms, which 'help states coordinate and collaborate so as to maximise utilities', assist 'order and constrain behaviour', and 'serve functional purposes: they regulate behaviour, reduce uncertainty by institutionalizing conventions, signal expectations, and reveal information' (Finnemore and Sikkink, 1998: 891; Shannon, 2000: 295; Spruyt, 2000: 69). As such, utilitarian norms help us to understand processes of international institutionalization (Manners, 1996: 41-43, 2000b: 28-29). Similarly, there are aspects of utilitarian norms at work 
in the institutional processes of procedural diffusion and transference diffusion discussed below.

Located within constructions of interpretivism are social norms, which are "constitutive of actor identity and interests', help 'create new actors, interests, or categories of action' and can be 'understood as a matrix of constitutive principles that govern the behaviours of members of a given social group' (Finnemore and Sikkink, 1998: 891; Shannon, 2000: 294-295; Spruyt, 2000: 68). Social norms help with the understanding of the constitution of communities and identities found in epistemic communities and role playing (Manners, 1996: 40-41, 43-44, 2000b: 27, 29-30). This approach corresponds roughly to the position taken by Kavalski (2013) in this special issue. Social norms are important in understanding the way the mechanisms of norm diffusion work, particularly in the constitutive processes of contagion diffusion and the cultural filter discussed below.

Prescribed within the domain of critical theory are maxim norms, which are 'irreducible to rationality or indeed to any other form of optimizing mechanism', represent the "prescriptive quality of "oughtness" and "refer to rules that distinguish moral from immoral actions and behaviours' (Finnemore and Sikkink, 1998: 891; Shannon, 2000: 295; Spruyt, 2000: 67). Within critical theory it is further possible to identify a number of different strands to thinking about such norms, including Antonio Gramsci's 'historical materialism', Jürgen Habermas's 'deliberative theory' and Craig Calhoun's 'critical social theory' (Manners, 2007a). This approach corresponds roughly to the position taken by Diez (2013) and Parker and Rosamond (2013) in this special issue. Maxim norms are important in understanding the way the mechanisms of norm diffusion work, particularly in the communicative and persuasive processes found in informational diffusion and procedural diffusion discussed below.

These three perspectives suggest that it might be possible to distinguish between utilitarian norms situated in a rational context, social norms situated in an intersubjective context and maxim norms situated in a prescriptive context. In his studies of the EU's normative power, Christopher Bickerton (2011a, 2011b) has contrasted two different normative theories, cosmopolitan law and communitarian social preferences, in the study of political legitimacy. Bickerton's discussion of cosmopolitan law draws on a Habermasian framework of three sources of legitimacy: pragmatic justification related to 'utilitarian norms'; ethical pragmatic justification related to 'social norms'; and moral justification related to 'maxim norms'. In contrast, his discussion of communitarian social preferences focuses on a means of combining theories of 'social norms' with those of 'utilitarian norms' found in 'interests' (contrast with Manners, in press-a).

Ordered within the strictures of postmodern science are narrative norms, which legitimate certain narratives and recognize that 'the ability to define normality interferes with virtually all aspects of the international' (Bleiker, 1998: 447). Finnemore and Sikkink appeared to recognize this when they suggested that 'one logical corollary to the prescriptive [moral] quality of norms is that, by definition, there are no bad norms from the vantage point of those who promote the norm' (Finnemore and Sikkink, 1998: 892), and thus bad norms are not normal. Florini put this well when she argued that it doesn't really matter how a norm arises, what is important is that it arises: 'no 
matter how a norm arises, it must take on an aura of legitimacy before it can be considered a norm' (Florini, 1996: 365). Within postmodern science, it is further possible to identify a number of different strands to thinking about narrative norms, including Friedrich Nietzsche's genealogy, Michel Foucault's governmentality and Jacques Derrida's deconstruction (Manners, 2006b, 2007a). Narrative norms provide an understanding of the way the mechanisms of norm diffusion work, particularly the structure and order of discourses in all six of the mechanisms of norm diffusion discussed in the next section.

In their study of EU normative power, Thomas Diez and Michelle Pace have placed their emphasis on the role of 'narrative norms' and the impact that a discourse of EU normative power has in conflict situations. Their work on conflict transformation identifies with a 'Foucauldian understanding of power' involving the study of the discursive construction of the EU. They focus on the notion of the 'power of reputation' and the way in which the 'discursive acceptance' of EU reputation is shared with conflict parties (Diez and Pace, 2011).

This reassessment of global theory leads to the suggestion that rethinking the nature of power, implicit in pouvoir normatif, provides a means of moving beyond the 16th century international system and into 21 st century global life. In order to rethink this move, it is useful to consider the mechanisms of norm diffusion found in examples of EU pouvoir normatif in action.

\section{'Pouvoir normatif' in action}

[W]e rely on moral persuasion, the power of argument, and the power of shaming ... Other factors in these circumstances of voluntary compliance are also important, such as the domestic salience of the norm, its legitimacy and coherence, and the extent to which it fits with other prevailing and well-established standards; but norms are expressed through language and the process of argumentation and debate can shape what is said subsequently in both domestic and international venues.

(Foot, 2000: 9, in Manners, 2008: 57)

In 2000, it was suggested that there were six means by which EU norms were diffused, drawing on Whitehead (1996), Manners and Whitman (1998) and Kinnvall (1995). As Rosemary Foot has suggested - in the case of engagement between the global community and China - persuasion, argument and shaming, in the context of salience, legitimacy and coherence, are all critical aspects of norm diffusion (see discussion in Manners, 2008: 57-58). For over a decade, these six 'mechanisms of normative power' (Forsberg, 2011: 1195) have been used to analyse pouvoir normatif in action (Manners, 2000a: 35-36, 2002: 244-245, 2006c: 46-47, 2006e: 76-81). The six mechanisms of norm diffusion - contagion, informational, procedural, transference, overt and cultural filter - are briefly revisited here. The global theories of these mechanisms of norm diffusion have already been briefly discussed above, facilitating the rethinking of power and pouvoir normatif (for overview see Manners, 2008: 57, 2009b: 793, 2011a: 235; see also Murray (2013), discussion of EU norms diffusion). 
The contagion diffusion of norms takes place through the diffusion of ideas between the EU and other global actors. An example of pouvoir normatif in action through contagion can be found in the ways in which ideas and means of regional integration have diffused between continents. Hence ideas such as the creation of a 'common high authority', 'four freedoms' and even 'single currency' are seen in other regions of the world as being worthy of imitation. Thus in both South America (Mercosur created in 1991, and UNASUR (Union of South American Nations) in 2011) and Africa (the move from the Organisation of African Unity to the African Union in 2002) regional organizations seek to imitate some of the perceived benefits of the EU. The African Union (AU) is particularly interesting in the way it sought to imitate the EU model: 'during the Lusaka Summit several references were made to the African Union being loosely based on the European Union model, in which respect it was said that Africa "should not re-invent the wheel", (Babarinde, 2007: 8; South African DFA, 2002). The AU is institutionally similar to the EU, with its administrative Commission, Executive Council of Member States' foreign ministers, Permanent Representatives Committee, Pan-African Parliament and Court of Justice. Contagion diffusion can sometimes be difficult to determine because the EU is actively engaging in inter-regional diplomacy through which it implicitly and explicitly promotes mimétisme (regional replication) with regions such as South America (Mercosur, UNASUR), Africa (SADC, AU) and south-east Asia (ASEAN, ASEM) (Manners and Whitman, 2003: 385). Contagion diffusion relies on a number of mechanisms of imitation, emulation and mimicry/mimétisme including the persuasive attraction of ideas, as well as the prestige and status associated with regional integration organizations.

As three examples illustrate, the contagion diffusion of norms in the EU can be seen in action in the cases of the Kyoto protocol, the UNESCO declaration of cultural diversity and the Ottawa landmines convention (Chan, 2013; Flowers, 2013). The role of the EU in promoting the 1997 Kyoto protocol to the 1992 Framework Convention on Climate Change suggests that the 'environmental imperative' drove the EU to adopt early measures and 'lead by example' (Baker, 2006; Manners, 2000b: 39-49; Vogler, 2005). In the case of cultural diversity, the lead taken by the EU on issues of 'cultural exception' since the 1994 Marrakesh ministerial meeting found form in the 2000 Council of Europe declaration on Cultural Diversity and the unprecedented adherence of the EU to the 2005 UNESCO Convention on the Protection and Promotion of the Diversity of Cultural Expressions as a regional organization of economic integration (Chan-Tibergien, 2006; Ferri, 2005). The third example of contagion diffusion suggests that the role of six EU-based non-governmental organizations (NGOs) from 1992 onwards was crucial in encouraging Member States to commit to the International Campaign to Ban Landmines and agree to the 1997 Treaty of Ottawa (Dover, 2006; Flowers, 2013; Long, 2002).

The informational diffusion of norms occurs through references to a range of strategic communications, such as new policy initiatives by the EU, and declaratory communications, such as initiatives from the Presidency of the EU or the president of the Commission. An example of EU pouvoir normatif in action through informational diffusion can be seen in the December 2003 European Security Strategy (ESS) with its reference to the 'complex causes' of terrorism, including 'the pressures of 
modernisation, cultural, social and political crises, and the alienation of young people living in foreign societies' (Solana, 2003:3). The informational diffusion of such norms, both inside and outside the EU institutions, relies on a number of mechanisms of initiation, declaration and communication including persuasive attraction and argumentative promotion of ideas.

Four examples of strategic communications initiated by the EU that spread informational diffusion of norms are as follows: the October 2003 Commission communication; the December 2003 European Security Strategy (ESS); the September 2004 Human Security Doctrine; and the December 2008 Report on the Implementation of the ESS (see Manners, in press-b). The October 2003 Commission communication on 'the choice of multilateralism' marked the first conscious step after the March 2003 unilateral invasion of Iraq to convey the centrality of the UN system to the EU: 'effective multilateralism ... means taking global rules seriously, whether they concern the preservation of peace or the limitation of carbon emissions; it means helping other countries to implement and abide by these rules; it means engaging actively in multilateral forums, and promoting a forward looking agenda that is not limited to a narrow defence of national interests' (Commission of the European Communities, 2003: 3). In December 2003 the European Council went further to agree an ESS that announced the strategic objective of effective multilateralism:

[i]n a world of global threats, global markets and global media, our security and prosperity increasingly depend on an effective multilateral system. The development of a stronger international society, well functioning international institutions and a rule-based international order is our objective.

(Solana, 2003: 9)

The September 2004 Barcelona Report proposed a new human security doctrine for the implementation of the ESS, including the principle of effective multilateralism, which has three basic aspects:

[f]irstly, it means a commitment to work with international institutions, and through the procedures of international institutions ... Secondly, multilateralism entails a commitment to common ways of working including agreed rules and norms: creating common rules and norms, solving problems through rules and co-operation, and enforcing the rules ... Thirdly, multilateralism also has to include coordination, rather than duplication or rivalry.

(Barcelona Study Group, 2004: 16-17; see also Kaldor, 2012; Martin, 2011)

The December 2008 Report on the Implementation of the 2003 ESS, in the section on 'Partnerships for Effective Multilateralism', argued that 'the ESS called for Europe to contribute to a more effective multilateral order around the world. Since 2003, we have strengthened our partnerships in pursuit of that objective' (Solana, 2008: 11).

The procedural diffusion of norms takes place through the institutionalization of relationships between the EU and third parties, involving political partnership as found in 
inter-regional cooperation agreements, membership of an international organization, association agreements or enlargement of the EU itself. An example of pouvoir normatif in action would include the way that, since 1995, EU relationships with over 120 countries have included an 'essential elements' clause referring to human rights and democracy, although in cases such as India and Burma these prove extremely controversial. Procedural diffusion relies on a number of mechanisms of partnership, cooperation, association and membership, including the persuasive attraction of ideas, the argumentative promotion of ideas, and the possible prestige and status of associating with the EU and other international organizations.

Examples of procedural diffusion in the EU's normative power can be found in the 20 association agreements identified by the External Action Service in May 2011 - including those with Albania, Bosnia and Herzegovina, Chile, Croatia, Macedonia, Montenegro, Serbia, South Africa and Turkey, and the EuroMediterranean Association Agreements. The EU's layers of institutionalized relationships include accession procedures, Stabilization and Association Agreements, the European Neighbourhood Policy (ENP) and Generalised System of Preferences 'plus' (GSP+) arrangements. Although these relationships include a variety of different procedures, they include discussion and diffusion of human rights, the environment and core labour standards to varying degrees. Examples of the procedural diffusion of norms include the essential element of effective implementation of UN core human rights conventions, International Labour Organization (ILO) core labour standards conventions and key environmental conventions in the EU's relations with its ENP partners (Commission of the European Communities, 2004: 12-13, 32-35; Manners, 2009b). Similarly, the arrangements that apply a scheme of GSP+ for non-LDC developing countries include the promotion of the principles found in the core UN and ILO human and labour rights conventions, as well as international conventions related to the environment and good governance (Council of the European Union, 2005).

The transference diffusion of norms occurs when the EU is involved in the transfer of material and immaterial assets such as humanitarian aid and technical assistance. As an example of pouvoir normatif in action, such transference may be the result of exportation through 'conditionality clauses', but is equally likely to be the result of more 'grass roots' engagement of EU agencies and support for NGOs on the ground without such conditions. Transference diffusion relies on a number of mechanisms of aid and assistance, engagement and support, including dialogue on, and transference of, ideas.

A controversial example of transference diffusion can be found in the April 2006 decision by Benita Ferrero-Waldner, External Relations Commissioner, to suspend payments to the newly elected Hamas government, but to increase aid to the Palestinian people through direct payments for aid to refugees and for fuel costs (Diez and Pace, 2011). Transference diffusion is thus most obvious in development aid and peacebuilding activities, with examples such as the activities in Aceh, Darfur and Palestine illustrating how these two policy areas are often deeply intertwined (Manners, 2007b). This transference diffusion can be seen in the role of the funding provided by the Rapid Reaction Mechanism, humanitarian aid provided by ECHO and the launching of a monitoring mission and an election observation mission in post-tsunami Aceh. Here the aim of the 
rule of law, human rights and democracy are part of the overall peace process and humanitarian effort.

The overt diffusion of norms occurs as a result of the physical presence of the EU in third states and international organizations. Examples of pouvoir normatif in action through overt diffusion include the role of European External Action Service delegations and embassies of Member States, or may involve the presence of one of the many presidents (European Council, Presidency, Commission or Parliament), the High Representative of the Union for Foreign Affairs and Security Policy or peacekeeping/ peacebuilding missions (e.g. see Björkdahl, 2011). Overt diffusion relies on a number of mechanisms of presence, diplomacy or actions including dialogue, transference or enforcement of ideas.

Attempts at the overt diffusion of human rights can be seen in the EU support for the creation of the UN Human Rights Council in 2006 and the EU human rights mission to the Philippines in 2007. Alongside Amnesty International and Human Rights Watch, the EU and its associated countries had pushed hard for the replacement of the discredited UN Human Rights Commission (HRC) by a new, strengthened UN Human Rights Council in 2006. However, within a year, the overt presence of the EU at the UN was felt again as the EU members of the HRC threatened to pull out in order to prevent rights abusers on the Council, such as China, Cuba, Russia, Saudi Arabia and Tunisia, from significantly weakening it. The adoption of the UN General Assembly resolution 65/276 in May 2011 marked a step forwards for the EU in terms of overt presence. The June 2011 EU Priorities for the 66th Session of the General Assembly of the United Nations set out how the EU intends to promote good global governance through reform of the UN system, including the revitalization of the General Assembly and the comprehensive reform of the Security Council, with the aim to enhance the efficiency, effectiveness, transparency, accountability and representativeness of the system. The EU's overt diffusion goes beyond its physical presence in international organizations to include delegations and missions in third countries. An example of this practice was the June 2007 EU human rights mission to Manila to identify the necessary technical assistance to help the Philippines find and prosecute state agents responsible for the extra-judicial killings and abductions of anti-government activists and leftist sympathizers.

The final factor shaping and transforming the diffusion of EU norms is the cultural filter. The cultural filter is based on the interplay between the construction of knowledge and the creation of social and political identity by the subjects of norm diffusion (Kinnvall, 1995: 61-71). The cultural filter involves a number of mechanisms of identity, domestic salience and the construction of knowledge, including the persuasive engagement, venues for dialogue and argument, and the transference and status of ideas.

Two aspects of EU global engagement serve as examples of the cultural filter at work in biodiversity (Feditchkina, 2013, Sakaguchi, 2013) and climate change negotiations. The refusal of the USA to ratify the 2000 Cartagena Protocol on Biosafety, the 1992 Convention on Biological Diversity or the 1997 Kyoto Protocol to the Framework Convention on Climate Change suggests that the local knowledge and identity construction regarding the environment is a powerful cultural filter. In the environmental arena the USA is not unique in this respect, as Australia and Russia 
have not ratified the Cartagena protocol. Furthermore the cases of landmines (Dover, 2006; Flowers, 2013; Long, 2002), Responsibility to Protect/R2P (Coleman, 2013; Manners, 2006d) and the International Criminal Court (Lee, 2013; Scheipers and Sicurelli, 2007, 2008; Sicurelli, 2010) suggest that the construction of sovereignty acts as a strong cultural filter to norm diffusion in a globalizing, multilateralizing and multipolarizing era.

\section{Conclusion: understanding European Union normative power in global politics}

The normative power of the discussion introduced in Manners' seminal article cannot be underestimated ... The NPE concept has enabled the EU studies community to escape the focus on specific institutions, policy domains and case studies, by engaging in a critical account of 'what the EU is and should be doing in world politics'. It has shifted attention to cross-cutting objectives pursued by the EU ... while also sparking a meta-theoretical debate on the nature of the EU and its power in the world. The NPE idea forces us to consider questions that, while most difficult to answer, are very much worth raising.

(Orbie, 2011: 160-161)

It has been argued that assessing the decennial and reassessing the global involves the rethinking of power and actorness, which are crucial aspects of understanding the EU and understanding normative power in global politics. This article has focused on the contributions to this special issue as the concept of pouvoir normatif in order to contribute to a better understanding of the EU in global politics. To do this the article first assessed the past decade in terms of engagement, internationalization and comparison. This also involved distinguishing between three meanings of normative power, before proceeding to assess the concept of pouvoir normatif more closely by differentiating between material incentives, physical force and normative justification. The second part of the article then argued that rethinking power and actorness involved reassessing global theory and pouvoir normatif in action. Jan Orbie (2006) reminds us that the real normative power of this discussion is in the way in which it moves the analytical focus from institutions, policies and cases towards a critical discussion of the EU in global politics. While illustrations from the contributors and the wider normative power field have been used throughout the article, there is no doubt that the ongoing work of analysis remains the way to advance the normative power of this discussion.

The contributors raise a number of questions regarding hegemony, neo-liberalism, naming, recognition and decentring. Many, if not most, of these questions resonate with ongoing challenges in the normative power research agenda, as two examples illustrate. Fisher Onar and Nicolaïdis (2013) explicitly (Kavalski, 2013, implicitly) raise the question of postcolonial perspectives on the NPA. This is a very important question which demands more attention than can be afforded here. However, as discussed elsewhere, it is also worth reflecting on the extent to which 'past European failures and crimes (such as colonialism, nationalism, world wars, the holocaust and inequality) [including] historical failures such as injustice, intolerance, and inhumanity' are part of the normative 
power narrative (Manners, 2006a: 174). Clearly there is also 'the obvious post-colonial concern that civilian power Europe is read as a neo-colonial attempt to "civilize" the world (again)' (Manners, 2006a: 174). As has been argued, invoking Gayatri Chakravorty Spivak, "Postcolonial theory makes absolutely clear that the term "civilization" is part of "Eurocentric strategies of narrativizing history, so that Europe can congratulate itself for progress" which in contemporary terms invokes the "culture of capitalism" (Spivak, 1999: 91, 93)' (Manners, 2006d: 184). Here the difference between communitarian, cosmopolitan and cosmopolitical normative theory becomes important, particularly in the context of globalization and neo-liberalism (Manners, in press-a). As Kinnvall has argued, there is a need to understand the 'mulifaceted nature of globalisation [...] in terms of a global-local nexus of dominance and resistance' using postcolonial, poststructural political theory and political psychology (Kinnvall, 2006: 11-35; Kinnvall and Nesbitt-Larking, 2010; Manners, 2011a: 227). Thus 'a communitarian emphasis on normative power as promoting European values raises concerns of neo-colonial hegemony', while 'post-colonial theory and concerns for neo-colonial practices must be explicit in attempts to understand how to judge and justify normative power' (Manners, 2011a: 245). As Spivak has emphasized, 'it is not just Eurocentric communitarian strategies that are problematic, but also the "culture of capitalism" which evokes a wider critique of neo-liberal cosmopolitanism' (Kinnvall, 2008; Manners, 2011a: 245; Spivak, 1999: 93).

Kavalski (2013), together with Fisher Onar and Nicolaïdis (2013), raises a second question of recognition and engagement between normative powers, between the self and others. This question is similar to that raised by Pierre Bourdieu of 'how do we create a really European Europe, one that is free from all the dependence on any of the imperialisms?' (Bourdieu, 1998: 129-130, in Manners, 2007a: 83). As discussed by Kavalski (2013), recognition involves interaction and deliberate relations, and, as has been suggested, 'both engagement and dialogue provide a means for reasoning with others implicated in EU external actions [where] dialogue means engaging in two-way deliberation and discussion as part of reasoning the merits of external actions' (Manners, 2008: 58; also Manners, 2010a: 40-43, 2011a: 235-237). Similarly, more empirical normative power studies have looked at "the "deliberative nature" and “deliberative approach" in EU foreign policy and external actions' (Manners, 2011a: 237). Such recognition and engagement 'should be seen as being part of an open-ended process of engagement, debate and understanding' (Manners, 2011a: 238; also Manners, 2010a: 41-44).

These two brief discussions illustrate some of the challenges the normative power research agenda faces in its second decade. Looking to the research agenda of its second decade, it can be suggested that the NPA could benefit from the development and application of its macro-approach, meso-characterization and micro-analysis. The macroapproach, using Parker and Rosamond's label, refers to the 'holistic research progammme' (Manners, 2011a: 246) of the NPA and the need to clarify the overall relationship between normative theory, methodological approach and analytical framework. Valuable contributions to the development of the macro-approach have been made by Elisabeth De Zutter (2010) and Tuomas Forsberg (2011), as well as Parker and Rosamond (2013) in this special issue. Vicki Birchfield (2011, in press) has gone further than most in 
developing and applying the NPA as a framework for the analysis of transnational policy formation. The meso-characterization, again to use Parker and Rosamond's label, refers to the 'characterisation of a type of actor' or puissance (Manners, 2011a: 231-233) within the NPA. The research agenda here is the need to develop and apply comparative analysis to regional organizations, international organizations, and state and non-state actors. Valuable contributions to the development of the meso-approach have been made by Nathalie Tocci (2008) and Emilian Kavalski (2012), as well as Keene (2013) and Kavalski (2013) in this special issue, but there is a further need to ask 'what the criteria are that define a normative power' (Keene, in press). The micro-analysis refers to the analysis of 'normative justification' as a 'form of power' or pouvoir within the NPA (Manners, 2011a: 230-231). The research agenda here is the need to develop both theoretical and empirical understandings of how the 'mechanisms of normative power' (Forsberg, 2011: 1195) function through empirical analysis and theoretical reflection. Edward Keene's (in press) discussion of 'social status' and Rebecca Adler-Nissan's (in press) notion of stigma both represent examples of how to take the micro-analysis of the NPA further in the future.

This article maintains, following Jan Orbie, that 'the normative power idea forces us to consider questions that, while most difficult to answer, are very much worth raising' (Orbie, 2011: 161). It has argued that there is now a broader international interest in using the NPA to attempt to explain, understand and judge the EU in global politics by rethinking the nature of power and actorness in a globalizing, multilateralizing and multipolarizing era. The article has concluded by setting out three ways of developing the NPA in its second decade: macro-approach, meso-characterization and micro-analysis. As Adler, Buzan and Dunne (2005) suggest, studying the normative foundations of power through the NPA combines the normative rethinking of power and actorness with the structural changes of a globalizing, multilateralizing and multipolarizing era.

\section{Acknowledgements}

The author would like to thank Richard Whitman and Kalypso Nicolaïdis, the reviewers, as well as Natalie Cole, Margherita Matera, Lachlan McKenzie, Siti Darwinda Mohamed Pero, Sandra Silfvast and Maurits Van der Veen for their helpful comments on this article.

\section{Funding}

This research received no specific grant from any funding agency in the public, commercial, or not-for-profit sectors.

\section{Note}

1. The normative power of EU is based on persuasion and argument, and not the action or the creation of structures for change. The power in this case is a discursive form that refers to the legitimacy and the coherent character of an argument. In his analysis, Manners focuses on the ideal impact of the identity and international role of the European Union. He introduced the concept of normative power (puissance normative), which is rooted in a historical context, a hybrid political system and a political-legal construction committed to contributing to the norms and universal principles in the centre of External Relations of the EU. 


\section{References}

Adler E and Crawford B (2006) Normative power: the European practice of region-building and the case of the Euro-Mediterranean partnership. In Adler E, Bicchi F, Beverly C, et al. (eds) The Convergence of Civilizations: Constructing a Mediterranean Region. Toronto, ON: University of Toronto Press, 3-47.

Adler E, Bicchi F, Cawford B, et al. (eds) (2006) The Convergence of Civilizations: Constructing a Mediterranean Region. Toronto, ON: University of Toronto Press.

Adler E Buzan B and Dunne T (2005) Forum afterword. Millennium: Journal of International Studies 34: 195-199.

Adler-Nissan R (2014) Stigma management in international relations: transgressive identities, norms and order in international society. International Organization 68(1).

Aggestam L (ed.) (2008) Ethical power Europe? International Affairs 84(1): 1-143.

Aron R (1986) Macht, power, puissance: democratic prose or demoniacal poetry? In: Lukes S (ed.) Power. New York: New York University Press, 253-277.

Babarinde $\mathrm{O}$ (2007) The EU as a model for the African Union: the limits of imitation. Jean Monnet/Robert Schuman Paper Series, vol. 7, no. 2, April. Available at: http://aei.pitt.edu/8185/1/ BabarindeEUasModellong07edi.pdf

Baker S (2006) Environmental values and climate change policy: contrasting the European Union and the United States. In: Lucarelli S and Manners I (eds) Values and Principles in European Union Foreign Policy. London: Routledge, 77-96.

Barcelona Study Group (2004) A human security doctrine for Europe: the Barcelona report of the study group on Europe's security capabilities. Presented to: EU High representative for common foreign and security policy Javier Solana, Barcelona, Spain, 15 September. Available at: http://www2.lse.ac.uk/internationalDevelopment/research/CSHS/humanSecurity/barcelonaReport.pdf

Bava US (2006) Emerging India and global norms: status Quoist or revisionist? In: International conference on 'Are European preferences Shared by Others? The Fate of European Norms in a Globalised World', Centre d'Etudes et de Recherches Internationales and Centre d'Etudes Européennes, Paris, France, 23-24 June.

Bickerton C (2011a) European Union Foreign Policy: From Effectiveness to Functionality. Basingstoke: Palgrave.

Bickerton C (2011b) Legitimacy through norms: the political limits to Europe's normative power. In: Whitman R (ed.) Normative Power Europe: Empirical and Theoretical Perspectives. Basingstoke: Palgrave, 25-42.

Birchfield V (2011) The EU's development policy: empirical evidence of 'Normative Power Europe'? In: Whitman R (ed.) Normative Power Europe: Empirical and Theoretical Perspectives. Basingstoke: Palgrave, 140-159.

Birchfield V (2013) A normative power Europe framework of transnational policy formation. Journal of European Public Policy 20(8).

Björkdahl A (2008) Norm advocacy: a small state strategy to influence the EU. Journal of European Public Policy 15(1): 135-154.

Björkdahl A (2011) Building peace: normative and military power in EU peace operations. In: Whitman R (ed.) Normative Power Europe: Empirical and Theoretical Perspectives. Basingstoke: Palgrave, 103-125.

Bleiker R (1998) Retracing and redrawing the boundaries of events: postmodern interferences with international theory. Alternatives 23: 471-497.

Boulding K (1989) Three Faces of Power. London: Sage.

Bourdieu P (1998) A reasoned utopia and economic fatalism. New Left Review 227: 125-130. 
Callahan W and Barabantseva E (eds) (2012) China Orders the World: Normative Soft Power and Foreign Policy. Washington, DC: Johns Hopkins University Press.

Chan J (2013) The UNESCO declaration of cultural diversity. In: Tiberghien Y (ed.) Leadership in Global Institution Building: Minerva's Rule. Basingstoke: Palgrave, 67-88.

Chan-Tibergien J (2006) Cultural diversity as resistance to neoliberal globalization: the emergence of a global movement and convention. International Review of Education 52(1): 89-105.

Chen S, Kangning X and Jun S (2012) 'Normative power Europe' and European economic integration. In: International Studies Association Annual Conference, San Diego, CA, 1-4 April.

Cochran M (1999) Normative Theory in International Relations: A Pragmatic Approach. Cambridge: Cambridge University Press.

Coleman K (2013) Minerva's allies: states, secretariats, and individuals in the emergence of the responsibility to protect norm. In: Tiberghien Y (ed.) Leadership in Global Institution Building: Minerva's Rule. Basingstoke: Palgrave, 150-169.

Commission of the European Communities (2003) The European Union and the United Nations: the Choice of Multilateralism. Communication from the Commission to the Council and the European Parliament. COM(2003) 526 final, 10 September, Brussels.

Commission of the European Communities (2004) European Neighbourhood Policy Strategy Paper. Communication from the Commission. COM(2004) 373 final, 12 May, Brussels.

Council of the European Union (2005) Council Regulation (EC) No. 980/2005 of 27 June 2005 applying a scheme of generalised tariff preferences. Official Journal of the European Union L 169: 1-43.

Cui H (2007) Normative power EU and the harmonious development of Sino-European relationship. Social Sciences 11: 54-61.

De Zutter E (2010) Normative power spotting: an ontological and methodological appraisal. Journal of European Public Policy 17(8): 1106-1127.

Diez T (2005) Constructing the self and changing others: reconsidering 'normative power Europe'. Millennium: Journal of International Studies 33(3): 613-636.

Diez T and Pace M (2011) Normative power Europe and conflict transformation. In: Whitman R (ed.) Normative Power Europe: Empirical and Theoretical Perspectives. Basingstoke: Palgrave, $210-255$.

Diez T (2013) Normative power as hegemony. Cooperation and Conflict 48(2): 194-210.

Dover R (2006) The EU's joint actions on anti-personnel mines and unexploded ordnance: finding a security policy identity. European Foreign Affairs Review 11(3): 401-416.

Dunne T (2008) Good citizen Europe. International Affairs 84(1): 13-28.

Dunne T (2012) Australia and the Security Council: temporary residency, lasting legacy. The Interpreter, Lowy Institute for International Policy, 18 October. Available at: http://www. lowyinterpreter.org/post/2012/10/18/Australia-and-the-Security-Council-TemporaryResidency-Lasting-Legacy.aspx

Etzioni A (1961) A Comparative Analysis of Complex Organizations. Glencoe, IL: Free Press.

Feditchkina E (2013) The Nagoya biosafety convention. In: Tiberghien Y (ed.) Leadership in Global Institution Building: Minerva's Rule. Basingstoke: Palgrave, 232-249.

Ferri D (2005) EU participation in the UNESCO convention on the protection of the diversity of cultural expressions: some constitutional remarks. European Diversity and Autonomy Papers 3: 1-34.

Finnemore M and Sikkink K (1998) International norm dynamics and political change. International Organization 52(4): 887-917.

Fisher Onar N and Nicolaïdis K (2013) The Decentring Agenda: Europe as a post-colonial power. Cooperation and Conflict 48(2): 283-303.

Florini A (1996) The evolution of international norms. International Studies Quarterly 40(3): 363-389. 
Flowers P (2013) The Ottawa process: domestic interests, transnational civil society and state identity. In: Tiberghien Y (ed.) Leadership in Global Institution Building: Minerva's Rule. Basingstoke: Palgrave, 111-130.

Foot R (2000) Rights Beyond Borders: The Global Community and the Struggle Over Human Rights in China. Oxford: Oxford University Press.

Forsberg T (2011) Normative power Europe, once again: a conceptual analysis of an ideal type. Journal of Common Market Studies 49(6): 1183-1204.

Forsberg T and Seppo A (2009) Power without influence? The EU and trade disputes with Russia. Europe-Asia Studies 61(10): 1805-1823.

Fukui E (2009) The EU perceptions in Asian citizens from the perspective of public opinion survey: a critical analysis of 'normative power Europe'. Hogaku seijigaku ronkyu: Journal of Law and Political Studies. 82: 37-67.

Fukui E (2012) Is the EU accepted as a normative power among Asian people? Public opinion surveys of six Asian countries. In: Japanese EU Gakkai Annual Conference, 10 November, Tokyo University.

Galbraith JK (1983) The Anatomy of Power. Boston, MA: Houghton Mifflin.

Galtung J (1989) Europe in the Making. New York: Crane Russak.

Gerrits A (ed.) (2009) Normative Power Europe in a Changing World: A Discussion. The Hague: Netherlands Institute of International Relations Clingendael.

Hamilton D (2008) The United States: a normative power? In: Tocci N (ed.) Who is a Normative Foreign Policy Actor? The European Union and Its Global Partners. Brussels: Centre for European Policy Studies, 76-155.

Hamilton L (2003) The Political Philosophy of Needs. Cambridge: Cambridge University Press.

Harpaz G (2007) Normative power Europe and the problem of a legitimacy deficit: an Israeli perspective. European Foreign Affairs Review 12(1): 89-109.

Harpaz G and Shamis A (2010) Normative power and the state of Israel: an illegitimate EUtopia? Journal of Common Market Studies 48(3): 579-616.

Haukkala H (2008) The European Union as a regional normative hegemon: the case of European Neighbourhood Policy. Europe-Asia Studies 60(9): 1601-1622.

Haukkala H (2011) The European Union as a regional normative hegemon: the case of European Neighbourhood Policy. In: Whitman R (ed.) Normative Power Europe: Empirical and Theoretical Perspectives. Basingstoke: Palgrave, 45-64.

Hong Y (2010) 'Normative power Europe' and its diplomacy to China. 世界经济与政治World Economics and Politics 1: 52-65.

Hosoya Y (2012) The evolution of the EU-Japan relationship: towards a 'normative partnership'? Japan Forum 24(3): 317-337.

Huber D (2012) Normative power Europe? The EU's foreign policy of democracy promotion in the Palestinian authority. Konrad-Adenauer-Stiftung - Israel Office, Working paper 98/2011.

Jackson J (1975) Normative power and conflict potential. Sociological Methods and Research 4(2): 237-239.

Ji L (2010) Speech, act and identity construction of 'normative power Europe'. European Studies 2: $33-45$.

Kaldor M (2012) The EU as a new form of political authority: the example of the common security and defence policy. Global Policy 3(s1): 79-86.

Kaldor M Martin M and Selchow S (2007) Human security: a new strategic narrative for Europe. International Affairs 83(2): 273-288.

Kavalski E (2012) Central Asia and the Rise of Normative Powers: Contextualizing the Security Governance of the European Union, China, and India. London: Continuum/Bloomsbury Academic. 
Kavalski E (2013) The struggle for recognition of normative powers: normative power Europe and normative power China in context. Cooperation and Conflict 48(2): 247-267.

Keene E (2013) Social status, social closure and the idea of Europe as a 'normative power'. European Journal of International Relations 19. Available at: http://ejt.sagepub.com/content/early/ 2012/06/19/1354066112437768.abstract

Keene E (2013) The naming of powers. Cooperation and Conflict 48(2): 268-282.

Kinnvall C (1995) Cultural Diffusion and Political Learning: The Democratization of China. Lund: Lund University Press.

Kinnvall C (2006) Globalization and Religious Nationalism in India: The Search for Ontological Security. London: Routledge.

Kinnvall C (2008) Gayatri Chakravorty Spivak. In: Edkins J and Vaughan-Williams N (eds) Critical Theorists and International Relations. London: Routledge, 317-329.

Kinnvall C and Nesbitt-Larking P (2010) Security, subjectivity and space in postcolonial Europe: Muslims in the diaspora. European Security 18(3): 305-326.

Kissack R (2009) Writing a new normative standard? EU Member States and ILO conventions. In: Orbie J and Tortell L (eds) The European Union and the Social Dimension of Globalization: How the EU Influences the World. Basingstoke: Palgrave, 98-112.

Kissack R (2010) Pursuing Effective Multilateralism: The European Union, International Organisations and the Politics of Decision Making. Basingstoke: Palgrave.

Kumar R (2008) India as a foreign policy actor: normative redux. In: Tocci N (ed.) Who is a Normative Foreign Policy Actor? The European Union and Its Global Partners. Brussels: Centre for European Policy Studies, 211-264.

Laïdi Z (ed.) (2008a) EU Foreign Policy in a Globalized World: Normative Power and Social Preferences. London: Routledge.

Laïdi Z (2008b) Norms Over Force: The Enigma of European Power. Basingstoke: Palgrave.

Lazarou E (2011) A model in crisis? Effects of the crisis in Europe on the influence of the EU as a model for regional integration in South America. In: Annual Meeting of the International Studies Association Annual Conference 'Global Governance: Political Authority in Transition', Montreal, QC, 16-19 March.

Lee J (2013) Enough rope: the role of Minervian actors in establishing the international criminal court. In: Tiberghien Y (ed.) Leadership in Global Institution Building: Minerva's Rule. Basingstoke: Palgrave, 213-231.

Long D (2002) The European Union and the Ottawa process to ban landmines. Journal of European Public Policy 9(3): 429-446.

Lucarelli S and Manners I (eds) (2006) Values and Principles in European Union Foreign Policy. London: Routledge.

McCormick N (1998) Powers and power-conferring norms. In: Paulson S and Paulson BL (eds) Normativity and Norms: Critical Perspectives on Kelsenian Themes. Oxford: Clarendon Press, 493-506.

Makarychev A (2008) Rebranding Russia: norms, politics and power. In: Tocci N (ed.) Who is a Normative Foreign Policy Actor? The European Union and Its Global Partners. Brussels: Centre for European Policy Studies, 156-210.

Manners I (1996) An anatomy of cooperation: achieving common policy in the New Europe. PhD Thesis, University of Bristol, UK.

Manners I (2000a) Normative power Europe: a contradiction in terms? Copenhagen Peace Research Institute, Working paper 38/2000.

Manners I (2000b) Substance and Symbolism: An Anatomy of Cooperation in the New Europe. Aldershot: Ashgate.

Manners I (2002) Normative power Europe: a contradiction in terms? Journal of Common Market Studies 40(2): 235-258. 
Manners I (2006a) The European Union as a normative power: a response to Thomas Diez. Millennium: Journal of International Studies 35(1): 167-180.

Manners I (2006b) European Union, normative power and ethical foreign policy. In: Chandler D and Heins V (eds) Rethinking Ethical Foreign Policy: Pitfalls, Possibilities and Paradoxes. London: Routledge, 116-136.

Manners I (2006c) L'identité internationale de l’Union européenne: un pouvoir normatif dans le jeu politique mondial. In: Adam B (ed.) Europe, puissance tranquille? Rôle et identité sur la scène mondiale. Brussels: Editions Complexe, 33-49.

Manners I (2006d) Normative power Europe reconsidered: beyond the crossroads. Journal of European Public Policy 13(2): 182-199.

Manners I (2006e) The symbolic manifestation of the European Union's normative role in world politics. In: Elgström O and Smith M (eds) New Roles for the European Union in International Politics. London: Routledge, 66-84.

Manners I (2007a) Another Europe is possible: critical perspectives on European Union politics. In: Jørgensen KE, Pollack M and Rosamond B (eds) Handbook of European Union Politics. London: Sage, 77-95.

Manners I (2007b) The normative power of the European Union in a globalised world. In: Laïdi Z (ed.) European Union Foreign Policy in a Globalised World: Normative Power and Social Preferences. London: Routledge, 23-37.

Manners I (2008) The normative ethics of the European Union. International Affairs 84(1): 45-60.

Manners I (2009a) The EU's international promotion of the rights of the child. In: Orbie J and Tortell L (eds) The European Union and the Social Dimension of Globalization: How the EU Influences the World. London: Routledge, 228-241.

Manners I (2009b) The social dimension of EU trade policies: reflections from a normative power perspective. European Foreign Affairs Review 14(5): 785-803 (J Orbie and L Tortell (eds) Special issue on The Social Dimension of European Union External Trade Relations).

Manners I (2010a) As you like it: European Union normative power in the European Neighbourhood Policy. In: Whitman R and Wolff S (eds) The European Neighbourhood Policy in Perspective: Context, Implementation and Impact. Basingstoke: Palgrave, 29-50.

Manners I (2010b) Global Europa: the mythology of the European Union in world politics. Journal of Common Market Studies 48(1): 67-87 (V Della Sala (ed.) Special issue on Mythologizing the European Union).

Manners I (ed.) (2010c) Normative power. Journal of European Public Policy. Available at: http:// www.tandf.co.uk/journals/access/rjpp.pdf

Manners I (2011a) The European Union's normative power: critical perspectives and perspectives on the critical. In: Whitman R (ed.) Normative Power Europe: Empirical and Theoretical Perspectives. Basingstoke: Palgrave, 226-247.

Manners I (2011b) Symbolism in European integration. Comparative European Politics 9(3): $243-268$.

Manners I (2013-a) European communion: political theory of European Union. Journal of European Public Policy 20(4): 473-494.

Manners I (2013-b) European [security] Union: bordering and governing a secure Europe in a better world? Global Society 27(3) (C Kinnvall (ed.) Borders, Security and Governance).

Manners I and Whitman R (1998) Towards identifying the international identity of the European Union: a framework for analysis of the EU's network of relations. Journal of European Integration 21(2): 231-249.

Manners I and Whitman R (2003) The 'difference engine': constructing and representing the international identity of the European Union. Journal of European Public Policy 10(3): $380-404$. 
Martin M (2011) Human security and the search for a normative narrative. In: Whitman R (ed.) Normative Power Europe: Empirical and Theoretical Perspectives. Basingstoke: Palgrave, $187-209$.

Mitzen J (2006) Anchoring Europe's civilizing identity: habits, capabilities and ontological security. Journal of European Public Policy 13(2): 270-285.

Mitzen J (2011) Governing together: global governance as collective intention. In: Bjola C and Kornprobst M (eds) Arguing Global Governance: Agency, Lifeworld, and Shared Reasoning. London: Routledge, 52-66.

Murray P (2010) Comparative regional integration in the EU and East Asia: moving beyond integration snobbery. International Politics 47: 308-323.

Murray P (2013) The EU's norms' entrepreneurship in regional integration. Working paper.

Orbie J (2006) Civilian power Europe: review of the original and current debates. Cooperation and Conflict 41: 123-128.

Orbie J (2011) Promoting labour standards through trade: normative power or regulatory state Europe? In: Whitman R (ed.) Normative Power Europe: Empirical and Theoretical Perspectives. Basingstoke: Palgrave, 160-183.

Pace M (2007) The construction of EU normative power. Journal of Common Market Studies 45(5): 1041-1064.

Pan Z (ed.) (2012) Conceptual Gaps in China-EU Relations: Global Governance, Human Rights and Strategic Partnerships. Basingstoke: Palgrave.

Parker O and Rosamond B (2013) 'Normative Power Europe' meets economic liberalism: complicating cosmopolitanism inside/outside the EU. Cooperation and Conflict 48(2): 229-246.

Patton SC (2009) The European Union as a Normative Power: Europe's New Neighbourhood and Energy Policies. Atlanta, GA: Georgia Institute of Technology.

Patton SC (2012) Hesitantly normative: the extension of the freedom of movement in the EU to the fifth enlargement states. In: International Studies Association Annual Conference, San Diego, CA, 1-4 April.

Poggi G (2001) Forms of Power. Cambridge: Polity, 15-28.

Poggi G (2006) Political power unmanned: a defence of the holy trinity from Mann's military attack. In: Hall J and Schroeder R (eds) An Anatomy of Power: The Social Theory of Michael Mann. Cambridge: Cambridge University Press, 135-149.

Polzer J, Mannix E and Neale M (1995) Multiparty negotiation in its social context. In: Kramer R and Messick D (eds) Negotiation as a Social Process: New Trends in Theory and Research. London: Sage, 123-142.

Romanova T (2009) Normative power Europe: a Russian view. In: Gerrits A (ed.) Normative Power Europe in a Changing World: A Discussion. The Hague: Netherlands Institute of International Relations Clingendael, 51-66.

Sakaguchi I (2013) Wildlife conservation and the development process of the CITES regime. In: Tiberghien Y (ed.) Leadership in Global Institution Building: Minerva's Rule. Basingstoke: Palgrave, 131-149.

Saurugger S (2010) Théories et concepts de l'intégration européenne. Paris: Presses de Sciences Po. Scheipers S and Sicurelli D (2007) Normative power Europe: a credible Utopia. Journal of Common Market Studies 45(2): 435-457.

Scheipers S and Sicurelli D (2008) Empowering Africa: normative power in EU-Africa relations. Journal of European Public Policy 15(4): 607-623.

Shannon V (2000) Norms are what states make of them: the political psychology of norm violation. International Studies Quarterly 44: 293-316.

Shen W (2011a) Eurocentric endeavour or empty rhetoric? Analysing EU promotion of human rights in China through a normative power perspective: 1989-2009. $\mathrm{PhD}$ Thesis, University of Bath, UK. 
Shen W (2011b) Normative power or empty rhetoric? The EU, human rights and the Tibet question. In: European Studies Association Biennial Conference, Boston, MA, 3-5 March.

Shen W (2012) Analysing the EU's promotion of human rights in China since 1989 through a 'normative power' perspective. In: Wetzel J (ed.) The EU as a 'Global Player' in Human Rights? London: Routledge, 113-130.

Sicurelli D (2010) European Union's Africa Policies: Norms, Interests and Impact. Farnham: Ashgate.

Sjursen H (ed.) (2006) Civilian or Military Power? The European Union at a Crossroads. London: Routledge.

Solana J (2003) A secure Europe in a better world: the European security strategy. Approved by the European Council held in Brussels on 12 December 2003 and drafted under the responsibilities of the EU High Representative Javier Solana.

Solana J (2008) Report on the implementation of the European security strategy - providing security in a changing world. Approved by the European Council held in Brussels on 11 and 12 December 2008 and drafted under the responsibilities of the EU High Representative Javier Solana.

Song L (2008) A study of EU characteristics: a normative model. International Forum 10(2).

Song L and Zhimin C (2011) The conceptual gap on soft power between China and Europe and its implications on the bilateral relations. Chinese Journal of European Studies 2.

South African DFA (2002) Transition from the OAU to the African Union. Department of Foreign Affairs, Republic of South Africa. Available at: http://www.au2002.gov.za/docs/background/ oau_to_au.htm

Spivak GC (1999) A Critique of Postcolonial Reason: Toward a History of the Vanishing Present. Cambridge, MA: Harvard University Press.

Spruyt H (2000) The end of empire and the extension of the Westphalian system: the normative basis of the modern state order. International Studies Review 2(2): 65-92.

Steinkohl J (2010) Normative power rivalry? The European Union, Russia and the question of Kosovo. College of Europe EU Diplomacy paper 6/2010. Bruges: College of Europe.

Stumbaum M-B (2012) How does Asia view the EU? Security in an interpolar world. NFG Working paper no. 1/2012 Berlin: Freie Universität Berlin.

Tiberghien Y (ed.) (2013) Leadership in Global Institution Building: Minerva's Rule. Basingstoke: Palgrave.

Tocci N (ed.) (2008) Who is a Normative Foreign Policy Actor? The European Union and Its Global Partners. Brussels: CEPS.

Tocci N and Manners I (2008) Comparing normativity in foreign policy: China, India, the EU, the US and Russia. In: Tocci N (ed.) Who is a Normative Foreign Policy Actor? The European Union and Its Global Partners. Brussels: Centre for European Policy Studies, 300-329.

Usui Y (2003) Evolving environmental norms in the European Union. European Law Journal 9(1): 69-87.

Usui Y (2011) Theories of EU politics and a normative model: normative power of multi-level governance? Research Conference of Japanese Political Science Association, October.

Vogler J (2005) The European contribution to global environmental governance. International Affairs 81(4): 835-850.

Wang Y (2009) The identity dilemmas of EU normative power: observations from Chinese traditional culture. In: Gerrits A (ed.) Normative Power Europe in a Changing World: A Discussion. The Hague: Netherlands Institute of International Relations Clingendael, 67-75.

Weber M (1968) The distribution of power within the political community: class, status, party. In: Roth G and Wittich C (eds) Economy and Society: An Outline of Interpretive Sociology. New York: Bedminster Press, 926-940.

Weber M (1991) Politics as a vocation. In: Gerth HH and Wright Mills C (eds) From Max Weber: Essays in Sociology. London: Routledge, 77-95. 
Whitehead L (1996) The International Dimension of Democratization: Europe and the Americas. Oxford: Oxford University Press.

Whitman R (ed.) (2011) Normative Power Europe: Empirical and Theoretical Perspectives. Basingstoke: Palgrave.

Womack B (2008) China as a normative foreign policy actor. In: Tocci N (ed.) Who is a Normative Foreign Policy Actor? The European Union and Its Global Partners. Brussels: Centre for European Policy Studies, 265-299.

Wood S (2009) The European Union: a normative or normal power? European Foreign Affairs Review 14: 113-128.

Wood S (2011) Pragmatic power EUrope? Cooperation and Conflict 46(2): 242-261.

Zhang M (2008) 'Normative power Europe': theory, reality or 'EU-topia'? European Studies 5: $1-16$.

\section{Author biography}

lan Manners is Professor in the Department of Political Science at the University of Copenhagen. 